\title{
Genomics and its Impact on Parasitology and the Potential for Development of New Parasite Control Methods
}

\author{
JOHN ELLIS, DAVID A. MORRISON and MICHAEL P. REICHEL ${ }^{1}$ \\ Institute for the Biotechnology of Infectious Diseases, \\ University of Technology, Sydney, \\ Westbourne St., Gore Hill, NSW 2065, Australia \\ 1“Yarrandoo” R\&D Centre, 245 Western Road, \\ Novartis Animal Health Australasia, \\ Kemps Creek NSW 2171, Australia
}

Correspondence to: Professor J.T. Ellis, Dept. of Cell \& Molecular Biology, University of Technology, Sydney, Westbourne St., Gore Hill, NSW 2065, Australia

Phone: 61-2-9514 4161

Fax: 61-2-9514 4003

Email: j.ellis@uts.edu.au 


\section{INTRODUCTION}

Parasitic organisms remain the scourge of the developed and underdeveloped worlds. Malaria, Schistosomiasis, Leishmaniasis and Trypanosomiasis still result in a large number of deaths each year (Anonymous, 2002), while drug resistance in malaria is increasing as a public health problem (Nosten and Brasseur, 2002). Similarly, resistance in parasitic worms is increasing at such an alarming rate that many drugs will soon be rendered useless

to the livestock industry (Sangster, 2001). It is therefore not surprising that genome projects on parasitic organisms are now abundant in the hope that new methods for the control of parasites will be forthcoming.

The purpose of this article is to review advances in the general area of parasite genomics, and to outline where the application of genomics and proteomics studies can impact on the development of new control methods for parasitic organisms. This review concentrates primarily on parasites of the phylum Apicomplexa, which includes malaria, Toxoplasma, Neospora and Eimeria. All these are important either medically or to the livestock industry.

\section{VACCINE DEVELOPMENT BEFORE THE GENOMICS ERA}

Commercially, vaccines based on live parasites (some naturally attenuated) are available and used successfully and extensively around the world for a limited number of parasite species. For example, live vaccines are available against besnoitiosis in cattle (Bigalke et al., 1974), Toxoplasma-induced abortion in sheep (Buxton and Innes, 1995) and coccidiosis in poultry (Chapman et al., 2002).

In contrast, few inactivated or subunit vaccines based on recombinant proteins have been developed against parasites (Lightowlers et al., 2000), but none for commercially 
important human or animal pathogens. There is great optimism however, that the application of the "omics" technologies will deliver new candidates for development into vaccines, and so more attention has been placed on gene discovery processes and the role of their products in parasite biology.

\section{Identifying vaccine candidates}

In the past, prior knowledge of induction of protective immunity in the host has been an essential prerequisite of any parasite vaccine program. For example, the malaria vaccine programs are founded primarily on two examples of immunity to malaria in humans : (1) naturally acquired immunity develops in those residing in malaria endemic areas (Carucci, 2001), and (2) irradiated sporozoites can protect humans against challenge. Of relevance to the animal health industry, it has long been recognised that Eimeria species induce a long-lasting, species specific immunity in the chicken (Chapman et al., 2002).

Previous approaches for identifying potential vaccine candidates have focussed on antigens which stimulate or are the target of host immunity (Jenkins, 2001) or molecules which are vital to infection (Lustigman et al., 2002). Identifying such molecules is not an easy task, given the complexity found in the diverse life cycle stages known to exist amongst parasites. Indeed these life cycle stages of parasites typically present a plethora of antigens to the host immune system.

In some circumstances, the life cycle stages involved in the presentation of protective antigens to the host can be determined. For example, studies on precocious lines of Eimeria (Shirley and Bedrnik, 1997) demonstrated that lines with abbreviated life cycles could still induce protection (McDonald et al., 1986; McDonald et al., 1988). An inactivated vaccine (NeoGuard) based on tachyzoites of Neospora caninum was developed 
to prevent Neospora-associated abortion in cattle, and this was recently released in the U.S.A. and New Zealand (Reichel and Ellis, 2002).

Screening of expression libraries with immune sera (or monoclonal antibodies) has become probably the most widespread approach for identifying antigens recognised by host antibody. This approach is limited by the fact that frequently humoral immunity is relatively unimportant in conferring protective immunity against a parasite. In addition, the approach has led to the characterisation of molecules in the past, which are typically abundant and highly expressed within the cell (Maizels et al., 2001).

One of the best examples utilising this approach successfully, however, is the correlation of maternal antibody-based immunity in the chicken with protection from infection by Eimeria maxima (Wallach et al., 1995). This led to the development of a vaccine using gametocyte antigens of this species, which are now the basis of a commercial vaccine (CoxAbic $\left.{ }^{\mathrm{TM}}\right)$.

Hidden antigens have shown great promise for some years now as vaccine candidates for parasitic nematodes. These are molecules that are normally hidden from the host immune system, and do not illicite an immune response during the course of a natural infection. Immunisation with native proteins of this type can induce a strong protective immune response (Knox and Smith, 2001), however commercial development of a subunit form of such a vaccine has not yet materialised.

\section{Cell-mediated responses}

For many parasitic diseases, the induction of cell-mediated immunity is paramount for successful vaccine production, and much has been learnt in recent years about the mechanisms and molecules which participate in these processes (Brake, 2002; Quinn et al., 2002). A Th1 response is seen as vital for induction of protective immunity against the 
Apicomplexa, and therefore selection of vaccine candidates which stimulate this type of immunity must warrant further consideration. One of the best examples from the protozoa relating to identification of vaccine candidates through their interaction with the cell mediated immune response was the identification of the LACK antigen (Leishmania homolog of receptors for activated C kinase) from Leishmania major (phylum Sarcomastigophora) as the main target of the Th2 response in mice which conferred susceptibility to leishmaniasis (Mougneau et al., 1995; Schilling and Glaichenhaus, 2001). Vaccination of mice using protein or DNA of LACK generated substantial levels of species-specific protective immunity to L. major (Gurunathan et al., 1997; Melby et al., 2001).

In summary, attempts to develop vaccines against parasitic organisms have thus far concentrated on relatively few molecules, and more often than not, these targets were isolated by techniques which selected for immunogens which are reasonably abundant in the cell. Studies on the genomes of parasites have expanded the population of genes and proteins available for study, and the issue at hand now is how to make best use of the information available.

\section{Laboratory models and screening}

The development of a laboratory model of infection, incorporating the features of immunisation schedules and challenge, greatly facilitates the screening of potential vaccine formulations. Animal models have now been developed for all pathogenic parasites of humans and animals. For example, cell free lysates of Eimeria tenella and N. caninum were shown to protect against coccidiosis in chickens and transplacental transmission of $N$. caninum in a mouse model respectively (Karkhanis et al., 1991; Liddell et al., 1999). 


\section{ANALYSES OF THE PARASITE TRANSCRIPTOME}

Initially, several approaches were used to define mRNA populations of parasitic organisms. Techniques such as differential display (Heard et al., 1996; Schroeder et al., 1998; Lau et al., 2000; Cui et al., 2001) and serial analysis of gene expression (Patankar et al., 2001) have played a role in gene discovery, yet 5' sequencing of random cDNA clones to generate expressed sequence tags has proven to be the most important approach, limited only by the quality of the cDNA libraries generated (Blackwell, 1997; Ajioka, 1998; Abrahamsen, 1999; Blaxter et al., 2002).

Clustering of ESTs and the generation of a consensus sequence for each cluster greatly facilitates the ease by which data can be rapidly assembled to generate a complete gene sequence (Lawson, 1999). It is interesting to note that many of the abundant ESTs of Apicomplexa encode antigens that have been well characterised in the past (Table 1) such as those found in the micronemes, dense granules and rhoptries.

Of importance is the accessibility of information and data in the public domain through a variety of internet-based resources, such as the Parasite Genome Internet Resource List (http://www.ebi.ac.uk/parasites/paratable.html), Parasite Genome Blast Server (http://www.ebi.ac.uk/blast2/parasites.html); Parasite Databases of Clustered Sequences (http://ParaDB.cis.upenn.edu/); Nembase (http://nema.cap.ed.ac.uk/nematodeESTs/nembase.html); and the Plasmodium and Toxoplasma genome resources (http://plasmodb.org/PlasmoDB.shtml; http://ToxoDB.org/ToxoDB.shtml).

Methods for searching sequence databases with new sequence data have proven to be fundamentally vital to parasite gene discovery programs. Algorithms like BLAST, when used in conjunction with large sequence datasets present in Genbank or other similar databases, readily assign a putative function through detecting sequence similarity. Of 
interest to vaccine development, however, is the very large number of parasite genes which exist for which no provisional identification can be made and about which nothing is as yet known (Table 1). Potentially this also proves to be a difficulty, because of the high throughput approaches that need to be developed in order to assess such a large number of vaccine candidates.

\section{Microarrays}

Recently expression profiling by microarray analyses (Carucci, 2000; Cummings and Relman, 2000; Rathod et al., 2002) has been reported from a small number of taxa (Hayward et al., 2000; Mamoun et al., 2001; Cleary et al., 2002; Matrajt et al., 2002; Singh et al., 2002), and no doubt the popularity of this technique will increase in parasitology as resources (such as clones and arrays) become more widely available. Such studies are proving important in raising and testing hypotheses on the developmental biology of parasites, and the signalling pathways that control them.

There is nothing inherently unique about microarray data or its analysis. In a microarray experiment one is simply trying to identify which genes are the most "interesting" in terms of the experimental question, and these will usually be those that are either over-expressed or under-expressed (or transiently expressed) under the experimental conditions being studied. However, the type of data analysis to be used will depend on the objective of the experiment. If the experimental question predicts an explicit pattern (e.g. differences in expression between developmental stages), then traditional statistical hypothesis testing is the best method for assessing whether the data support or refute that pattern. Alternatively, if the experimental question is about searching for unknown patterns among the samples (e.g. groups of genes that show co-expression) then multivariate pattern analysis is the best method for exploring the patterns that might exist in the data. A detailed 
discussion can be found in the introductory book by (Knudsen, 2002).

Statistical hypothesis testing is no different for microarray data than for any other type of data. However, there are issues that are particularly important for such data, and some of them have been discussed previously (Nadon and Shoemaker, 2002; Yang and Speed, 2002). Specialist computer programs have also been developed (Didier et al., 2002). Similarly, multivariate pattern analysis is a general mathematical technique in science, although there are many alternative methods. Some of these methods are briefly described in the context of microarray data analysis by others and so will not be discussed further (Hess et al., 2001; Quackenbush, 2001; Raychaudhuri et al., 2001; Sherlock, 2001). (Eisen et al., 1998) describe a commonly used computer program for carrying out the analyses.

Microarrays are also being used to investigate changes in gene expression of host cells during parasite infection in order to investigate host response mechanisms (Blader et al., 2001; Gail et al., 2001). Real-time quantitative RT-PCR analysis, using fluorogenic 5’nuclease assays, or Taqman, is typically used to confirm and quantify gene expression levels (Blair et al., 2002).

As yet, no reports have described simultaneous analyses of gene expression in the host as well as in the parasite as they interact with each other. This clearly would be a fascinating approach to adopt.

\section{SEQUENCING OF PARASITE GENOMES}

Table 2 lists all genome projects for parasites being conducted through either the Sanger Centre (U.K.)(http://www.sanger.ac.uk/Projects/) or The Institute for Genome Research (USA)(http://www.tigr.org/tdb/parasites/). The approaches being adopted are similar in structure for each, concentrating on sequence assembly from whole genome shotgun sequencing approaches (Gardner, 2001). Initially, some of the projects began on a 
chromosome by chromosome basis, with different groups taking responsibility for individual chromosomes (Gardner et al., 1998; Bowman et al., 1999). Strategically, this approach was important because it facilitated the leverage of funds from a number of public and private bodies, and demonstrated proof of concept that parasite genomes could be sequenced. However the power of shotgun sequencing realistically has made approaches based on individual chromosomes redundant for protozoa, and more dependent on the tools of bioinformatics for compiling and annotating the genome sequences generated. For example, the high AT content of the P. falciparum genome coupled with the recognised gene density of $20 \%$, required the development and training of new gene finder algorithms such as GlimmerM (Salzberg et al., 1999) and Phat (Cawley et al., 2001). Even then, manual searches are proving just as effective in making robust gene predictions (Huestis and Fischer, 2001). Despite these difficulties, the genome sequence of $P$. falciparum was recently reported (Gardner et al., 2002), and this presents an outstanding opportunity to explore many different aspects of the biology of this parasite.

The genomes of parasitic worms, being much larger than those of protozoa, will take some considerable time to investigate, although EST programs are prevalent and rapidly defining the genetic component of these organisms. Projects to survey the genomes of Brugia malayi and Schisotosoma mansoni are underway. The generation and analyses of such large volumes of data is daunting, yet it potentially provides many new exciting opportunities for gene discovery which may result in the development of new parasite control methods.

\section{LINKAGE ANALYSES}

The ability to perform classical genetic crosses using cloned lines of parasites of defined phenotype represents an outstanding advantage for investigating unique traits in 
some parasitic organisms. For example, acute virulence in $T$. gondii is recognised as an inherited, multigenic trait (Howe et al., 1996; Sibley et al., 2002), precocious development in Eimeria was assigned to chromosome 2 (Shirley and Harvey, 2000) and a gene with a functional role in malarial gametocytogenesis was assigned to chromosome 12 (Guinet and Wellems, 1997). Such studies, in conjunction with pulsed-field gel electrophoresis and DNA markers, not only confirm the number of linkage groups (and hence the number of chromosomes) present (Shirley et al., 1990; Sibley and Boothroyd, 1992; Hays et al., 1995), but also provides a framework on which genome sequences can be overlaid and correlated. Hence, positional cloning with the help of physical genetic maps and genome sequences may materialise gene loci central to parasite development and pathogenesis. HAPPY mapping is a relatively simple method for assigning and ordering DNA markers to chromosomes (Dear and Cook, 1993), and was first used to produce a linkage map of the genome of C. parvum (Piper et al., 1998). More recently, it has found use in GAP closure in the P. falciparum genome, where there was a paucity of markers for ordering of the contigs (Gardner, 2001). The main advantage of this approach for mapping genomes of lower eukaryotes is its relative simplicity, and so will find further widespread use in the study of protozoa.

\section{COMPARATIVE GENOMICS}

Comparisons of parasite genomes from closely related species is now providing valuable information not only on genome organization but also on gene function (Thompson et al., 2001; Waters, 2002). In malaria research, karyotype analyses demonstrated conservation of chromosome structure amongst both rodent and human malarias (Janse et al., 1994; Carlton et al., 1999), and this work has aided the identification of homologous genes amongst species (Thompson et al., 2001). In addition, genetic 
manipulation of $P$. berghei is somewhat more amenable than for $P$. falciparum, thereby facilitating functional studies through targeted disruption (Waters et al., 1997).

Functional genomics may also prove valuable in the study of other protozoan parasites. For example, in vitro culture and transfection of Eimeria species of poultry is not yet possible and so genetic manipulation of its genome is difficult. Comparisons of genome sequences from different Eimeria species may assist in studies of gene identification and function. Similarly, T. gondii and $N$. caninum are closely related species, but relatively little is known about the genome of the latter. Sequencing and mapping of the $N$. caninum genome, and its comparison to that of $T$. gondii, may ultimately shed light on the unique biological features of this organism.

\section{ANALYSES OF THE PARASITE PROTEOME}

The investigation of protein-protein interactions is fundamentally central to the investigation of parasite-host interactions. The processes of host cell recognition, attachment and invasion require the interaction of a large number of parasite surface and organelle specific molecules with those present on host cells (Hemphill, 1999). Determination of their identity and function can provide potential vaccine targets.

The key technologies behind the core of proteome analyses, namely twodimensional gel electrophoresis coupled to mass spectroscopy and data base searching, have been described in detail elsewhere (Barrett et al., 2000; Ashton et al., 2001). Recently large scale analyses of parasite proteomes have been reported (Jefferies et al., 2001; Cohen et al., 2002) and the available data shows that it is un-necessary to possess whole genome sequence data in order to make proteomic analyses viable. Large numbers of proteins are being identified merely from database searches of peptide fragmentation data. 
Post-translational modifications of proteins clearly exist, but this whole area is vastly underexplored from a vaccine viewpoint and so presents many potential opportunities. Glycosylphosphatidylinositols have been extensively studied in protozoa for their role as membrane anchors and in cell signalling (Schofield and Tachado, 1996), and more recently their role in activating a Toll-like receptor recognition system may have important implications for vaccine design (Campos et al., 2001). Mice immunised with a synthetic GPI designed from malaria were substantially protected against malarial acidosis, pulmonary oedema, cerebral syndrome and fatality (Schofield et al., 2002).

Currently there are few attempts to group genes and proteins into functional categories. The Parasite Proteome Server (http:www.ebi.ac.uk/parasites/proteomes.html) was the first attempt to do this, but other information sources are now being developed that may facilitate the incorporation and integration of additional biological information (Coppel, 2001). The InterPro database (http://www.ebi.ac.uk/interpro/), which is an assemblage of others for defining gene families, signatures and domains, is proving useful in this respect along with Gene Ontology assessments (http://www.geneontology.org/). The illucidation of metabolic pathways will prove vital to the development of new control methods based on drugs (Fairlamb, 2002).

\section{GENETIC MANIPULATION OF PARASITES}

The development of a wide range of molecular genetics tools for T. gondii, such as transformation and a variety of gene disruption technologies, has propelled this organism into the forefront of parasite genetics [Sibley, 1993 \#1796; Donald, 1993 \#1532; Donald, 1995 \#1529; Soldati, 1996 \#1350; Boothroyd, 1997 \#932; Roos, 1997 \#961; Donald, 1998 \#1523; Black, 1998 \#1346; Brecht, 1999 \#1791; Soete, 1999 \#1790; Knoll, 2001 \#1039; Sibley, 2002 \#1631]. Although some of these techniques have also been developed for 
parasites such as Plasmodium (de Koning-Ward et al., 2000; Cowman et al., 2002), and are probably easily transferable to other species such as N. caninum (Howe and Sibley, 1997), advanced genetic manipulations are currently impossible for many others such as Eimeria or Sarcocystis. RNA interference methodologies, although available for Trypanosoma brucei (Ullu et al., 2002), are not yet commonplace for the Apicomplexa (McRobert and McConkey, 2002).

Probably the main value to be gained from applying these techniques to the study of parasites is an advanced knowledge on the distribution, localisation and function of individual molecules. This can facilitate an assessment of their role in parasite virulence and pathogenesis. Many of the knock-outs generated typically show no discernable change in cell phenotype, and so many of these lines may not be rigorously pursued for further investigation. However the creation of knock-out mutants, and the restoration of the gene and wild-type function back to these mutants, is required to fulfil a molecular version of Koch's postulates (Falkow, 1988).

\section{VACCINES AND IMMUNOTHERAPIES}

The generation of genome sequences facilitates access to all potential targets of immunity, and so they can be used in a number of novel ways. The use of reverse vaccinology is growing, being increasingly dependent on the tools of bioinformatics (Rappuoli, 2000; Rappuoli, 2001). Sequence databases are searched (mined) for molecules that are predicted to possess some novel trait, such as being secreted or membrane bound. Genes are identified coding for molecules which may play an important role in the parasite life cycle, pathogenesis or immune evasion. Subsequently, these molecules are tested in animal models for their ability to induce protective immunity. 
The development of high-throughput approaches has been needed to screen large numbers of vaccine candidates in a rational, un-biased fashion. The majority of these have used the DNA vaccination approach, with candidates being assessed individually or in pools (Almeida et al., 2002). Expression library immunisation has also been used directly as a screening method in conjunction with animal models, for the identification of vaccine candidates (Melby et al., 2000; Smooker et al., 2000). This later approach is recognised to be limited in its ability to identify vaccine candidates because of the phenomenon of masking of protection, which can occur by individual members of the group.

The development of novel live vaccines through the use of genetic manipulation technologies has exciting potential. To date, auxotrophic mutants of Leishmania and $T$. gondii created by knock-out strategies, have been shown to be attenuated and to be able to induce strong protective immunity (Titus et al., 1995; Fox and Bzik, 2002). Issues such as persistence of the live vaccine or reversion to the virulent phenotype within the vaccinated population remain a concern, but nevertheless these issues are potentially addressable.

\section{IDENTIFICATION OF NEW DRUG TARGETS}

Investigations into the genomes of parasitic protozoa have also identified many new, potentially exciting targets for chemotherapeutic treatment, such as enzymes of folate metabolism, the mannitol cycle and polyamine biosynthesis for example (Coombs and Muller, 2002). Some of the most exciting advances come from the characterisation of the apicoplast, a novel remnant of a chloroplast which is essential for parasite survival (McFadden and Roos, 1999; Ralph et al., 2001). Plastid genomes in Apicomplexa are similar to those found in bacteria, and some known drugs like Ciprofloxacin, selectively target the apicoplast (Fichera and Roos, 1997). 
Another good example of drug development is the discovery of fosmidomycin as an antimalarial compound and this has been described in some detail elswhere (Anonymous, 2002). Briefly, mining of the malaria genome database demonstrated that the parasite used the non-mevalonate pathway for isoprenoid synthesis, which is absent in humans. Inhibitors of this pathway had been available for some time, and through the use of mouse models were found to be effective antimalarial compounds (Jomaa et al., 1999).

The identification of the shikimate pathway in Apicomplexa is also worth noting, since this pathway is missing in mammals and is a target for herbicides in plants (Roberts et al., 2002). Indeed glyphosphate, which targets 5-enolpyruvyl shikimate 3-phosphate synthase, shows anti-parasitic activity (Roberts et al., 1998).

The large numbers of parasite genes and proteins which remain to be characterised imply that we know relatively little about the metabolic pathways of parasites and that many more remain to be discovered. Hence it is highly likely that new drug targets will be identified in the future (Fairlamb, 2002).

\section{SUMMARY}

There is no doubt the era of the "omics" is with parasitology, and current trends in the discipline are addressing fundamental biological questions that can make best use of the new technologies, as well as the vast amount of new data being generated. Genes, currently uncharacterised, will be identified that are involved in the host-parasite interaction and we will learn more about parasite biology and pathogenesis. Attempts to explain the diversity of phenotypic traits shown by parasites will occur using genome sequence data, and new parasite-specific biochemical pathways and mechanisms of drug-resistance will be identified. In addition, the host response to parasites will be investigated, and the mechanisms used by parasites to evade immunity will be explained. This surely will 
become the "golden age of molecular parasitology", leading to the control of parasitic diseases which have plagued mankind for hundreds of years. 


\section{REFERENCES}

Abrahamsen, M.S. (1999). Cryptosporidium parvum gene discovery. Adv. Exp. Med. \& Biol. 473, 241-247.

AJIOKA, J.W. (1998). Toxoplasma gondii: ESTs and gene discovery. Int. J. Parasitol. 28, 1025-1031.

Almeida, R., Norrish, A., LeVick, M., Vetrie, D., Freeman, T., Vilo, J., IVens, A., LAnge, U., StOBer, C., McCann, S. and Blackwell, J.M. (2002). From genomes to vaccines: Leishmania as a model. Phil. Trans. Roy. Soc. Lond. - Series B: Biol. Sci. 357, 5-11.

AnONYMous. (2002) Genomics and World Health. Advisory Committee on Health Research, World Health Organisation, Geneva.

Ashton, P.D., CuRWEN, R.S. and WiLSON, R.A. (2001). Linking proteome and genome: how to identify parasite proteins. Trends Parasitol. 17, 198-202.

BARRETT, J., JEFFERIES, J.R. and BROPHY, P.M. (2000). Parasite proteomics. Parasitol.Today 16, 400-403.

BigalKe, R.D., SChOEMAN, J.H. and McCully, R.M. (1974). Immunization against bovine besnoitiosis with a live vaccine prepared from a blue wildebeest strain of Besnoitia besnoiti grown in cell cultures. 1. Studies on rabbits. Onders. J. Vet. Res. 41, 1-5.

BlACKWELL, J.M. (1997). Parasite genome analysis. Progress in the Leishmania genome project. Trans. Roy. Soc. Trop. Med. \& Hyg. 91, 107-110.

Blader, I.J., MANGER, I.D. and BoOthroyd, J.C. (2001). Microarray analysis reveals previously unknown changes in Toxoplasma gondii-infected human cells. J. Biol. Chem. 276, 24223-24231. 
Blair, P.L., Witney, A., Haynes, J.D., Moch, J.K., CARUCCI, D.J. and AdAMs, J.H. (2002). Transcripts of developmentally regulated Plasmodium falciparum genes quantified by real-time RT-PCR. Nucl. Acids Res. 30, 2224-2231.

Blaxter, M., Daub, J., Guiliano, D., Parkinson, J., Whitton, C. and Filarial GenOME, P. (2002). The Brugia malayi genome project: expressed sequence tags and gene discovery. Trans. Roy. Soc. Trop. Med. \& Hyg. 96, 7-17.

BOOTHROYD, J.C., BLACK, M., BONNEFOY, S., HEHL, A., KNOLL, L.J., MANGER, I.D., ORTEGA-BARRIA, E. and TOMAVO, S. (1997). Genetic and biochemical analysis of development in Toxoplasma gondii. Phil. Trans. Roy. Soc. Lond. - Series B: Biol. Sci. 352, 1347-1354.

Bowman, S., Lawson, D., Basham, D., Brown, D., Chillingworth, T., Churcher, C.M., Craig, A., Davies, R.M., Devlin, K., Feltwell, T., Gentles, S., Gwilliam, R., Hamlin, N., Harris, D., Holroyd, S., Hornsby, T., Horrocks, P., Jagels, K., Jassal, B., Kyes, S., McLean, J., Moule, S., Mungall, K., MurPhy, L., OLIVER, K. and ET AL. (1999). The complete nucleotide sequence of chromosome 3 of Plasmodium falciparum. Nature 400, 532-538.

BRAKE, D.A. (2002). Vaccinology for control of apicomplexan parasites: a simplified language of immune programming and its use in vaccine design. International Journal for Parasitology 32, 509-515.

BUXTon, D. and INNES, E.A. (1995). A commercial vaccine for ovine toxoplasmosis. Parasitology 110(Suppl), S11-16.

Campos, M.A.S., Almeida, I.C., TaKeuchi, O., AKira, S., Valente, E.P., Procopio, D.O., Travassos, L.R., Smith, J.A., Golenbock, D.T. and Gazzinelli, R.T. (2001). Activation of toll-like receptor-2 by glycosylphosphatidylinositol anchors from a protozoan parasite. J. Immunol. 167, 416-423. 
Carlton, J.M., Galinski, M.R., BARnwell, J.W. and DAme, J.B. (1999). Karyotype and synteny among the chromosomes of all four species of human malaria parasite. Mol. Biochem. Parasitol. 101, 23-32.

CARUCCI, D.J. (2000). Malaria research in the post-genomic era. Parasitol. Today 16, 434438.

CARUCCI, D.J. (2001). Genomic tools for gene and protein discovery in malaria: toward new vaccines. Vaccine 19(17-19), 2315-2318.

CAWLEY, S.E., WIRTH, A.I. and SPEED, T.P. (2001). Phat--a gene finding program for Plasmodium falciparum. Mol. Biochem. Parasitol. 118, 167-174.

Chapman, H.D., Cherry, T.E., DAnforth, H.D., Richards, G., Shirley, M.W. and WiLLIAMS, R.B. (2002). Sustainable coccidiosis control in poultry production: the role of live vaccines. Int. J. Parasitol. 32, 617-629.

Cleary, M.D., Singh, U., Blader, I.J., Brewer, J.L. and Boothroyd, J.C. (2002). Toxolasma gondii asexual development:Identification of developmentally regulated genes and distinct patterns of gene expression. Eukaryotic Cell 1, 329-340.

Cohen, A.M., Rumpel, K., CoOmBS, G.H. and WAstling, J.M. (2002). Characterisation of global protein expression by two-dimensional electrophoresis and mass spectrometry: proteomics of Toxoplasma gondii. Int. J. Parasitol. 32, 39-51.

CoOmbS, G.H. and Muller, S. (2002). Recent advances in the search for new anticoccidial drugs. Int. J. Parasitol. 32, 497-508.

COPPEL, R.L. (2001). Bioinformatics and the malaria genome: facilitating access and exploitation of sequence information. Mol. Biochem. Parasitol. 118, 139-145.

Cowman, A.F., Baldi, D.L., Duraisingh, M., HeAler, J., Mills, K.E., O'Donnell, R.A., Thompson, J., Triglia, T., WiCKHAM, M.E. and CRABB, B.S. (2002). Functional analysis of Plasmodium falciparum merozoite antigens: implications for erythrocyte 
invasion and vaccine development. Phil. Trans. Roy. Soc. Lond. - Series B: Biol. Sci. 357, 25-33.

Cui, L., Rzomp, K.A., Fan, Q., Martin, S.K. and Williams, J. (2001). Plasmodium falciparum: differential display analysis of gene expression during gametocytogenesis. Exp. Parasitol. 99, 244-254.

CUMmings, C.A. and RELMAN, D.A. (2000). Using DNA microarrays to study hostmicrobe interactions. Emerg. Infect. Dis. 6, 513-525.

DE Koning-WARD, T.F., JANSE, C.J. and Waters, A.P. (2000). The development of genetic tools for dissecting the biology of malaria parasites. Ann. Rev. Microbiol. 54, 157185.

DEAR, P.H. and COOK, P.R. (1993). Happy mapping: linkage mapping using a physical analogue of meiosis. Nucl. Acids Res. 21, 13-20.

Didier, G., BrÉzellec, P., Remy, E. and HéNAut, A. (2002). GeneANOVA — gene expression analysis of variance. Bioinformatics 18, 490-491.

Eisen, M.B., Spellman, P.T., Brown, P.O. and Botstein, D. (1998). Cluster analysis and display of genome-wide expression patterns. Proc. Nat. Acad. Sci. U. S. A. 95, 14863-14868.

FAIRLAMB, A.H. (2002). Metabolic pathway analysis in trypanosomes and malaria parasites. Phil. Trans. Roy. Soc. Lond. - Series B: Biol. Sci. 357, 101-107.

FALKOW, S. (1988). Molecular Koch's postulates applied to microbial pathogenicity. Rev. Infect. Dis. 10(Suppl 2), S274-276.

FicherA, M.E. and Roos, D.S. (1997). A plastid organelle as a drug target in apicomplexan parasites. Nature 390, 407-409.

Fox, B.A. and BzIK, D.J. (2002). De novo pyrimidine biosynthesis is required for virulence of Toxoplasma gondii. Nature 415, 926-929. 
GaIL, M., Gross, U. and BoHNE, W. (2001). Transcriptional profile of Toxoplasma gondiiinfected human fibroblasts as revealed by gene-array hybridization. Mol. Genet. \& Gen.: MGG 265, 905-912.

GARDNER, M.J. (2001). A status report on the sequencing and annotation of the $P$. falciparum genome. Mol. Biochem. Parasitol. 118, 133-138.

Gardner, M.J., Hall, N., Fung, E., White, O., Berriman, M., Hyman, R.W., CARlton, J.M., Pain, A., Nelson, K.E., Bowman, S., Paulsen, I.T., James, K., Eisen, J.A., Rutherford, K., SAlzberg, S.L., Craig, A., Kyes, S., Chan, M.S., Nene, V., Shallom, S.J., Suh, B., Peterson, J., Angiuoli, S., PerteA, M., Allen, J., Selengut, J., Haft, D., Mather, M.W., VAidya, A.B., Martin, D.M., FAirlamb, A.H., Fraunholz, M.J., Roos, D.S., RalPh, S.A., McFadden, G.I., Cummings, L.M., Subramanian, G.M., Mungall, C., Venter, J.C., Carucci, D.J., Hoffman, S.L., Newbold, C., Davis, R.W., Fraser, C.M. and Barrell, B. (2002). Genome sequence of the human malaria parasite Plasmodium falciparum. Nature. 419, 498-511.

Gardner, M.J., TetTelin, H., Carucci, D.J., Cummings, L.M., ARAvind, L., KoOnin, E.V., Shallom, S., Mason, T., Yu, K., FujiI, C., Pederson, J., Shen, K., Jing, J.P., Aston, C., Lai, Z.W., Schwartz, D.C., Pertea, M., Salzberg, S., Zhou, L.X., Sutton, G.G., Clayton, R., White, O., Smith, H.O., Fraser, C.M., AdAms, M.D., HOFFMAN, S.L. and ET AL. (1998). Chromosome 2 sequence of the human malaria parasite Plasmodium falciparum. Science 282, 1126-1132.

Guinet, F. and Wellems, T.E. (1997). Physical mapping of a defect in Plasmodium falciparum male gametocytogenesis to an $800 \mathrm{~kb}$ segment of chromosome 12. Mol. Biochem. Parasitol. 90, 343-346. 
Gurunathan, S., SACKs, D.L., Brown, D.R., Reiner, S.L., ChaRest, H., Glaichenhaus, N. and SEDER, R.A. (1997). Vaccination with DNA encoding the immunodominant LACK parasite antigen confers protective immunity to mice infected with Leishmania major. J. Exp. Med. 186, 1137-1147.

HAYs, M.P., MosieR, D.A. and OBERST, R.D. (1995). Enhanced karyotype resolution of Cryptosporidium parvum by contour-clamped homogeneous electric fields. Vet. Parasitol. 58, 273-280.

Hayward, R.E., Derisi, J.L., Alfadhli, S., Kaslow, D.C., Brown, P.O. and Rathod, P.K. (2000). Shotgun DNA microarrays and stage-specific gene expression in Plasmodium falciparum malaria. Mol. Microbiol. 35, 6-14.

HEARD, P.L., LEWIS, C.S. and CHAUDHURI, G. (1996). Leishmania mexicana amazonensis: differential display analysis and cloning of mRNAs from attenuated and infective forms. J. Euk. Microbiol. 43, 409-415.

HemphiLl, A. (1999). The host-parasite relationship in neosporosis. Adv. Parasitol. 43, 47104.

Hess, K.R., Zhang, W., BAgGerly, K.A., Stivers, D.N. and CoOmBes, K.R. (2001). Microarrays: handling the deluge of data and extracting reliable information. Trends Biotech. 19, 463-468.

Howe, D.K. and SiBLEY, L.D. (1997). Development of molecular genetics for Neospora caninum - A complementary system to Toxoplama gondii. Methods 13, 123-133.

Howe, D.K., Summers, B.C. and SiBley, L.D. (1996). Acute virulence in mice is associated with markers on chromosome VIII in Toxoplasma gondii. Infect. Immun. 64, 5193-5198.

Huestis, R. and FisCHER, K. (2001). Prediction of many new exons and introns in Plasmodium falciparum chromosome 2. Mol. Biochem. Parasitol. 118, 187-199. 
Janse, C.J., CARlton, J.M.R., WALliker, D. and WATERS, A.P. (1994). Conserved location of genes on polymorphic chromosomes of four species of malaria parasites. Mol. Biochem. Parasitol. 68, 285-296.

JefFeries, J.R., CAmpbell, A.M., van Rossum, A.J., BARretT, J. and Brophy, P.M. (2001). Proteomic analysis of Fasciola hepatica excretory-secretory products. Proteomics 1, 1128-1132.

JENKINS, M.C. (2001). Advances and prospects for subunit vaccines against protozoa of veterinary importance. Vet. Parasitol. 101, 291-310.

JomaA, H., Wiesner, J., SAnderbrand, S., AltinciceK, B., Weidemeyer, C., Hintz, M., Turbachova, I., EBerl, M., Zeidler, J., LiChtenthaler, H.K., SoldATi, D. and BECK, E. (1999). Inhibitors of the nonmevalonate pathway of isoprenoid biosynthesis as antimalarial drugs. Science 285, 1573-1576.

Karkhanis, Y.D., Nollstadt, K.A., Bhogal, B.S., Ravino, O., Pellegrino, R., Crane, M.S., Murray, P.K. and Turner, M.J. (1991). Purification and characterization of a protective antigen from Eimeria tenella. Infect. Immun. 59, 983-989.

KNOX, D.P. and SMITH, W.D. (2001). Vaccination against gastrointestinal nematode parasites of ruminants using gut-expressed antigens. Vet. Parasitol. 100, 21-32.

KNUDSEN, S. (2002). A biologist's guide to analysis of DNA microarray data. John Wiley \& Sons, New York.

LAU, A.O., SACCI, J.B., JR. and AZAD, A.F. (2000). Retrieving parasite specific liver stage gene products in Plasmodium yoelii infected livers using differential display. Mol. Biochem. Parasitol. 111, 143-151.

LAwSON, D. (1999). Data mining parasite genomes: haystack searching with a computer. Parasitology 118(Suppl), S15-18. 
LidDell, S., Jenkins, M.C., ColliCA, C.M. and Dubey, J.P. (1999). Prevention of vertical transfer of Neospora caninum in BALB/c mice by vaccination. J. Parasitol. 85, 1072-1075.

Lightowlers, M.W., Flisser, A., Gauci, C.G., Heath, D.D., Jensen, O. and Rolfe, R. (2000). Vaccination against cysticercosis and hydatid disease. Parasitol. Today 16, 191-196.

Lustigman, S., JAmEs, E.R., TAWE, W. and ABrahAM, D. (2002). Towards a recombinant antigen vaccine against Onchocerca volvulus. Trends Parasitol. 18, 135-141.

MAIZELS, R.M., BLAXTER, M.L. and SCOTT, A.L. (2001). Immunological genomics of Brugia malayi: filarial genes implicated in immune evasion and protective immunity. Parasite Immunol. 23, 327-344.

Mamoun, C.B., Gluzman, I.Y., Hott, C., MacMillan, S.K., AmaraKone, A.S., Anderson, D.L., Carlton, J.M.R., Dame, J.B., Chakrabarti, D., Martin, R.K., BROWNSTEIN, B.H. and GOLDBERG, D.E. (2001). Co-ordinated programme of gene expression during asexual intraerythrocytic development of the human malaria parasite Plasmodium falciparum revealed by microarray analysis. Mol. Microbiol. 39, 26-36.

Matrajt, M., DonALD, R.G.K., Singh, U. and RoOs, D.S. (2002). Identification and characterization of differentiation mutants in the protozoan parasite Toxoplasma gondii. Mol. Microbiol. 44, 735-747.

McDonald, V., Rose, M.E. and JEFFERS, T.K. (1986). Eimeria tenella: immunogenicity of the first generation of schizogony. Parasitology 93, 1-7.

McDonald, V., Wisher, M.H., Rose, M.E. and JefFers, T.K. (1988). Eimeria tenella: immunological diversity between asexual generations. Parasite Immunol. 10, 649660. 
MCFADDEN, G.I. and Roos, D.S. (1999). Apicomplexan plastids as drug targets. Trends Microbiol. 7, 328-333.

MCRoBert, L. and MCCONKEY, G.A. (2002). RNA interference (RNAi) inhibits growth of Plasmodium falciparum. Mol. Biochem. Parasitol. 119, 273-278.

Melby, P.C., Ogden, G.B., Flores, H.A., Zhao, W., Geldmacher, C., Biediger, N.M., AhUJA, S.K., URAnGA, J. and MeLEndez, M. (2000). Identification of vaccine candidates for experimental visceral leishmaniasis by immunization with sequential fractions of a cDNA expression library. Infect. Immun. 68, 5595-5602.

Melby, P.C., YANG, J., ZhaO, W., Perez, L.E. and Cheng, J. (2001). Leishmania donovani p36(LACK) DNA vaccine is highly immunogenic but not protective against experimental visceral leishmaniasis. Infect. Immun. 69, 4719-4725.

Mougneau, E., Altare, F., WaKil, A.E., Zheng, S., Coppola, T., WANG, Z.E., WALDMANN, R., LOCKSLEY, R.M. and GlaichenHAUs, N. (1995). Expression cloning of a protective Leishmania antigen. Science 268, 563-566.

NADON, R. and SHOEMAKER, J. (2002). Statistical issues with microarrays: processing and analysis. Trends Genet 18, 265-271.

Nosten, F. and BrasseuR, P. (2002). Combination therapy for malaria: the way forward? Drugs 62, 1315-1329.

Patankar, S., Munasinghe, A., ShoAibi, A., Cummings, L.M. and Wirth, D.F. (2001). Serial analysis of gene expression in Plasmodium falciparum reveals the global expression profile of erythrocytic stages and the presence of anti-sense transcripts in the malarial parasite. Mol. Biol. Cell 12, 3114-3125.

PIPER, M.B., BANKIER, A.T. and DEAR, P.H. (1998). A HAPPY map of Cryptosporidium parvum. Genome Res. 8, 1299-1307. 
QuACKenBuSH, J. (2001). Computational analysis of microarray data. Nature Rev. Gen. 2, 418-427.

QuinN, H.E., ELLIS, J.T. and SMITH, N.C. (2002). Neospora caninum: a cause of immunemediated failure of pregnancy? Trends Parasitol. 18, 391-394.

RALPH, S.A., D'OMBrain, M.C. and McFadDEN, G.I. (2001). The apicoplast as an antimalarial drug target. Drug Res. Updates 4, 145-151.

RAPPUOLI, R. (2000). Reverse vaccinology. Curr. Opin. Microbiol. 3, 445-450.

RAPPUOLI, R. (2001). Reverse vaccinology, a genome-based approach to vaccine development. Vaccine 19, 2688-2691.

RATHOD, P.K., GANESAN, K., HAYWARD, R.E., BozDECH, Z. and DeRisi, J.L. (2002). DNA microarrays for malaria. Trends Parasitol. 18, 39-45.

RAYCHAUdhURI, S., SutPhin, P.D., ChANG, J.T. and AltMAN, R.B. (2001). Basic microarray analysis: grouping and feature reduction. Trends Biotech. 19, 189-193.

ReICHEL, M.P. and ELLIS, J.T. (2002). Control options for Neospora caninum in cattle. New Zeal. Vet. J. 50, 86-92.

Roberts, C.W., Roberts, F., Lyons, R.E., KIRISITS, M.J., MuI, E.J., FINNERTY, J., Johnson, J.J., Ferguson, D.J., Coggins, J.R., Krell, T., CoOmBS, G.H., Milhous, W.K., Kyle, D.E., Tzipori, S., Barnwell, J., Dame, J.B., Carlton, J. and MCLEOD, R. (2002). The shikimate pathway and its branches in apicomplexan parasites. J. Inf. Dis. 185(Suppl 1), S25-36.

Roberts, F., Roberts, C.W., Johnson, J.J., Kyle, D.E., Krell, T., CogGins, J.R., CoOmbs, G.H., Milhous, W.K., Tzipori, S., Ferguson, D.J., ChaKrabarti, D. and MCLEOD, R. (1998). Evidence for the shikimate pathway in apicomplexan parasites. Nature 393, 801-805. 
Salzberg, S.L., Pertea, M., Delcher, A.L., Gardner, M.J. and Tettelin, H. (1999).

Interpolated Markov models for eukaryotic gene finding. Genomics. 59, 24-31.

SANGSTER, N.C. (2001). Managing parasiticide resistance. Vet. Parasitol. 98, 89-109.

SCHILLING, S. and GLAichenHAus, N. (2001). T cells that react to the immunodominant Leishmania major LACK antigen prevent early dissemination of the parasite in susceptible BALB/c mice. Infect. Imm. 69, 1212-1214.

Schofield, L., Hewitt, M.C., Evans, K., Siomos, M.A. and Seeberger, P.H. (2002). Synthetic GPI as a candidate anti-toxic vaccine in a model of malaria. Nature $\mathbf{4 1 8}$, 785-789.

SCHOFIELD, L. and TACHADO, S.D. (1996). Regulation of host cell function by glycosylphosphatidylinositols of the parasitic protozoa. Immunol. Cell Biol. 74, 555-563.

Schroeder, A.A., Brown, A.M. and AbrahAmSEN, M.S. (1998). Identification and cloning of a developmentally regulated Cryptosporidium parvum gene by differential mRNA display PCR. Gene 216, 327-334.

SHERLOCK, G. (2001). Analysis of large-scale gene expression data. Briefings in Bioinformatics 2(4), 350-362.

SHIRLEY, M.W. and BEDRNIK, P. (1997). Live attenuated vaccines against avian coccidiosis - success with precocious and egg-adapted lines of Eimeria. Parasitol. Today 13, 481-484.

SHIRLEY, M.W. and HARVEY, D.A. (2000). A genetic linkage map of the apicomplexan protozoan parasite Eimeria tenella. Genome Res. 10, 1587-1593.

Shirley, M.W., KemP, D.J., PALlister, J. and Prowse, S.J. (1990). A molecular karyotype of Eimeria tenella as revealed by contour-clamped homogeneous electric field gel electrophoresis. Mol. Biochem. Parasitol. 38, 169-173. 
SIBLEY, L.D. and BoOTHROYD, J.C. (1992). Construction of a molecular karyotype for Toxoplasma gondii. Mol. Biochem. Parasitol. 51, 291-300.

Sibley, L.D., Mordue, D.G., Su, C.L., Robben, P.M. and Howe, D.K. (2002). Genetic approaches to studying virulence and pathogenesis in Toxoplasma gondii. Phil. Trans. Roy. Soc. Lond. Series B: Biol. Sci. 357, 81-88.

Singh, U., BREWER, J.L. and BOOTHROYD, J.C. (2002). Genetic analysis of tachyzoite to bradyzoite differentiation mutants in Toxoplasma gondii reveals a hierarchy of gene induction. Mol. Microbiol. 44, 721-733.

SMOOKER, P.M., SETIADY, Y.Y., RAincZUK, A. and SpithiLL, T.W. (2000). Expression library immunization protects mice against a challenge with virulent rodent malaria. Vaccine 18, 2533-2540.

THOMPSON, J., JANSE, C.J. and WATERS, A.P. (2001). Comparative genomics in Plasmodium: a tool for the identification of genes and functional analysis. Mol. Biochem. Parasitol. 118, 147-154.

Titus, R.G., Gueiros-Filho, F.J., DE Freitas, L.A. and BeverLey, S.M. (1995).

Development of a safe live Leishmania vaccine line by gene replacement. Proc. Nat. Acad. Sci. U. S. A. 92, 10267-10271.

UlLu, E., DJIKENG, A., SHI, H. and TschUdi, C. (2002). RNA interference: advances and questions. Phil. Trans. Roy. Soc. Lond. - Series B: Biol. Sci. 357, 65-70.

Wallach, M., Smith, N.C., Petracca, M., Miller, C.M., Eckert, J. and Braun, R. (1995). Eimeria maxima gametocyte antigens: potential use in a subunit maternal vaccine against coccidiosis in chickens. Vaccine 13, 347-354.

WATERS, A.P. (2002). Orthology between the genomes of Plasmodium falciparum and rodent malaria parasites: possible practical applications. Phil. Trans. Roy. Soc. Lond. - Series B: Biol. Sci. 357, 55-63. 
Waters, A.P., Thomas, A.W., VAnDIJK, M.R. and JAnse, C.J. (1997). Transfection of malaria parasites. Methods 13, 134-147.

YANG, Y.H. and SPEED, T. (2002). Design issues for cDNA microarray experiments. Nature Reviews Genetics 3, 579-588. 
TABLE 1. SUMMARY OF THE 20 MOST ABUNDANT ESTS IN THREE COCCIDIAN SPECIES (http://ParaDB.cis.upenn.edu/) ${ }^{1}$

\begin{tabular}{|c|c|c|}
\hline Toxoplasma gondii & Neospora caninum & Eimeria tenella \\
\hline GRA7 & GRA2 & Antigen \\
\hline GRA1 & GRA7 & Actophorin \\
\hline \multirow[t]{2}{*}{ GRA2 } & UNCHARACTERISED & Serine protease \\
\hline & CLUSTER (neo_566) & inhibitor \\
\hline \multirow[t]{3}{*}{ GRA6 } & MIC1 & UNCHARACTERISED \\
\hline & & CLUSTER \\
\hline & & (Ceimqual_264) \\
\hline \multirow[t]{2}{*}{$P 22$} & UNCHARACTERISED & MIC1 \\
\hline & CLUSTER (neo_617) & \\
\hline \multirow[t]{3}{*}{ Р30 } & GRA1 & UNCHARACTERISED \\
\hline & & CLUSTER \\
\hline & & (Ceimqual_287) \\
\hline \multirow[t]{3}{*}{ HSP3O } & MIC10 & UNCHARACTERISED \\
\hline & & CLUSTER \\
\hline & & (Ceimqual_521) \\
\hline \multirow[t]{3}{*}{ NTPase } & P38 & UNCHARACTERISED \\
\hline & & CLUSTER \\
\hline & & (Ceimqual_1487) \\
\hline UNCHARACTERISED & SUL1 & UNCHARACTERISED \\
\hline CLUSTER & & CLUSTER \\
\hline (Ctoxoqual4_276) & & (Ceimqual_953) \\
\hline
\end{tabular}




\begin{tabular}{|c|c|c|}
\hline GRA5 & UNCHARACTERISED & UNCHARACTERISED \\
\hline & CLUSTER (neo_824) & CLUSTER \\
\hline & & (Ceimqual_926) \\
\hline UNCHARACTERISED & Serine protease & MIC2 \\
\hline CLUSTER & inhibitor & \\
\hline (Ctoxoqual4_5857) & & \\
\hline GRA3 & NTPase & Calmodulin \\
\hline SAG1 & Serine protease & UNCHARACTERISED \\
\hline & & CLUSTER \\
\hline & & (Ceimqual_566) \\
\hline UNCHARACTERISED & UNCHARACTERISED & UNCHARACTERISED \\
\hline CLUSTER & CLUSTER (neo_378) & CLUSTER \\
\hline (Ctoxoqual4_64) & & (Ceimqual_714) \\
\hline H4 antigen & MIC4 & UNCHARACTERISED \\
\hline & & CLUSTER \\
\hline & & (Ceimqual_775) \\
\hline GRA5 & UNCHARACTERISED & UNCHARACTERISED \\
\hline & CLUSTER (neo_150) & CLUSTER \\
\hline & & (Ceimqual_218) \\
\hline$R O P 2$ & UNCHARACTERISED & Cytochrome C oxidase \\
\hline & CLUSTER (neo_549) & \\
\hline UNCHARACTERISED & UNCHARACTERISED & TA4 antigen \\
\hline CLUSTER & CLUSTER (neo_759) & \\
\hline (Ctoxoqual4_3035) & & \\
\hline
\end{tabular}




\begin{tabular}{lll} 
GRA8 & MIC6 & UNCHARACTERISED \\
& & CLUSTER \\
& & (Ceimqual_758) \\
UNCHARACTERISED & UNCHARACTERISED & UNCHARACTERISED \\
CLUSTER & CLUSTER (neo_287) & CLUSTER \\
(toxoqual4_4452) & & (Ceimqual_161) \\
\hline
\end{tabular}

${ }^{1}$ GRA, dense granule protein; MIC, microneme protein; ROP, rhoptry protein 


\section{TABLE 2. SUMMARY OF PARASITE GENOME PROJECTS BEING}

CONDUCTED THROUGH THE SANGER INSTITUTE OR TIGR

\begin{tabular}{|c|c|c|c|}
\hline Species & $\begin{array}{c}\text { Number of } \\
\text { chromosomes, } \\
\text { genome size } \\
\text { (Mb) }\end{array}$ & Comments ${ }^{1}$ & Useful web-sites $^{2}$ \\
\hline $\begin{array}{l}\text { Plasmodium } \\
\text { falciparum }^{3}\end{array}$ & 14,30 & WG & $\begin{array}{l}\text { http://www.plasmodb.org; } \\
\text { SI; TIGR }\end{array}$ \\
\hline $\begin{array}{l}\text { Plasmodium } \\
\text { yoelli }^{3}\end{array}$ & & WG & TIGR \\
\hline $\begin{array}{l}\text { Theileria } \\
\text { annualata }\end{array}$ & 4,10 & WG & SI, TIGR \\
\hline $\begin{array}{l}\text { Toxoplasma } \\
\text { gondii }\end{array}$ & $11,, 80$ & WG & $\begin{array}{l}\text { http://ToxoDB.org/ToxoDB.shtml } \\
\text { http://ParaDB.cis.upenn.edu/ } \\
\text { SI, TIGR }\end{array}$ \\
\hline Eimeria tenella & 14,60 & WG & SI \\
\hline $\begin{array}{l}\text { Trypanosoma } \\
\text { brucei }\end{array}$ & $11+, 35$ & WG & $\begin{array}{l}\text { http://parsun1.path.cam.ac.uk/ } \\
\text { http://www.genedb.org/ } \\
\text { SI, TIGR }\end{array}$ \\
\hline $\begin{array}{l}\text { Trypanosoma } \\
\text { cruzi }\end{array}$ & 35,40 & PG & http://www.dbbm.fiocruz.br/genome/tcruzi/tcruzi.html \\
\hline Leishmania major & 36, 33.6 & WG & $\begin{array}{l}\text { http://www.genedb.org/ } \\
\text { SI, TIGR }\end{array}$ \\
\hline
\end{tabular}




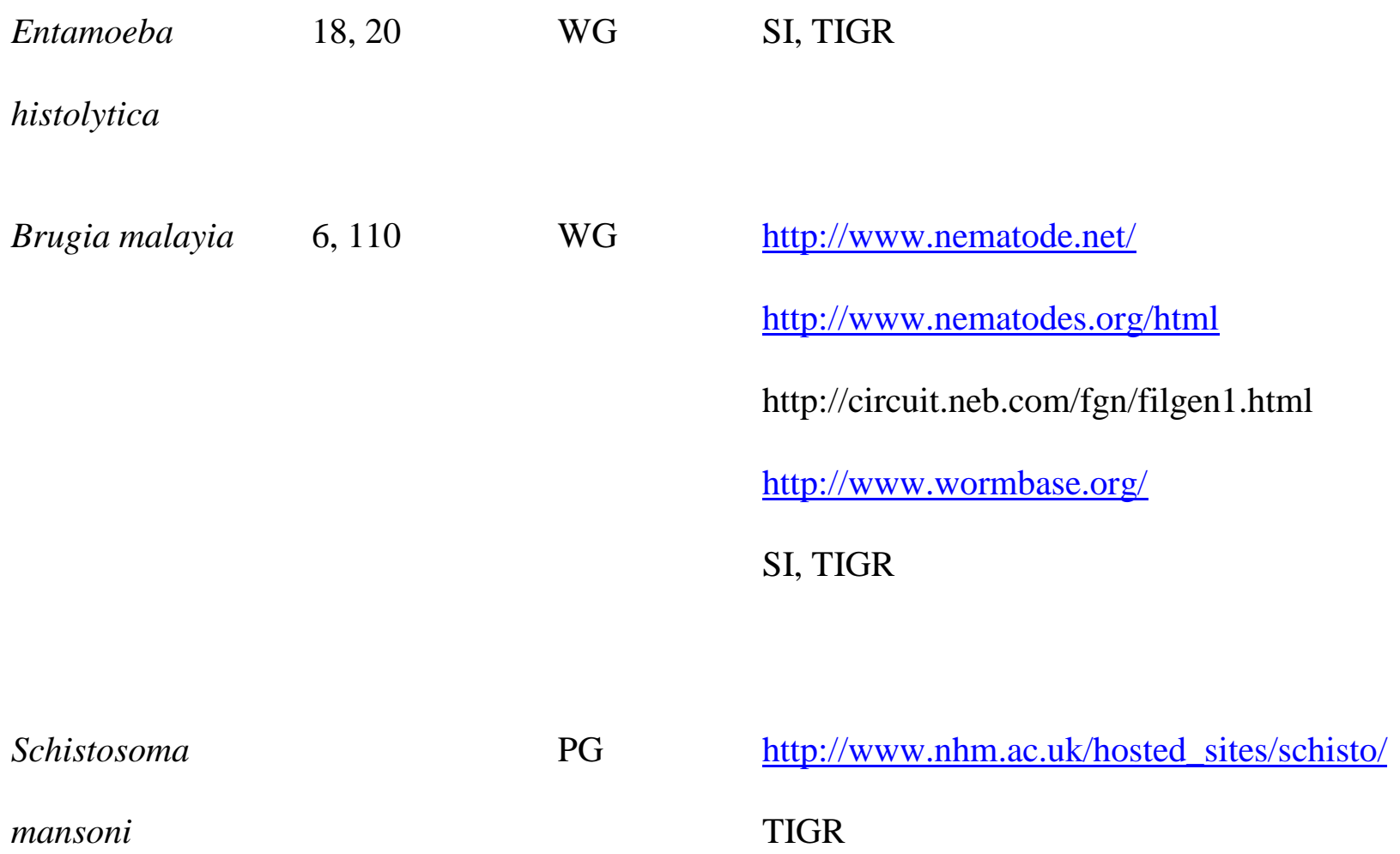

${ }^{1}$ WG, Whole genome, PS, Partial genome; ${ }^{2}$ SI, Sanger Institute

(http://www.sanger.ac.uk/Projects/); TIGR, The Institute for Genome Research

(http://www.tigr.org/tdb/parasites/); ${ }^{3}$ partial shortguns are also being generated for

P. berghei, P. chabaudi and P. knowlesi. 
